\title{
Kualitas hidup manula yang menggunakan gigi tiruan lengkap berdasarkan OHIP-14 di Kota Makassar (Quality of life of elderly using complete denture based on OHIP-14 in Makassar)
}

\author{
${ }^{1}$ Muzdalifah Solina Berutu, ${ }^{2}$ Moh. Dharmautama \\ ${ }^{1}$ Mahasiswi tahap profesi \\ ${ }^{2}$ Bagian prostodonsia \\ Fakultas Kedokteran Gigi Universitas Hasanuddin \\ Makassar, Indonesia
}

\begin{abstract}
Complete dentures are not always functioning well in replacing teeth. Mastication, esthetics and phonetic has been known to affect the quality of life. This study aims to determine the quality of life of elderly who use the full denture. Descriptive analytic research with cross sectional study design was conducted in Makassar on May-June 2014. The sample was obtained by stratified random sampling, by conducting interviews based on OHIP-14 questionnaires, door to door on 162 elderly respondents. The results show that the highest score of the seven dimensions of OHIP-14 is on the dimensions of physical disability, and the lower the score obtained, the better the quality of life. This research obtained a mean score of 50.58, so it was concluded that the quality of life of the elderly in Makassar which uses the full denture was categorized as good.
\end{abstract}

Key words: complete denture, elderly, quality of life

\begin{abstract}
ABSTRAK
Penggunaan gigi tiruan lengkap pada manula tidak selamanya berfungsi secara baik. Fungsi-fungsi mastikasi, estetik dan fonetik telah diketahui dapat mempengaruhi kualitas hidup. Penelitian ini bertujuan untuk mengetahui kualitas hidup manula yang menggunakan gigi tiruan lengkap. Penelitian deskriptif analitik dengan desain cross sectional study ini dilakukan di Kota Makassar pada bulan Mei sampai Juni 2014. Sampel diperoleh dengan teknik stratified random sampling, dengan melakukan wawancara berdasarkan kuesioner OHIP-14, dari rumah ke rumah pada 162 responden manula yang menggunakan gigitiruan penuh. Hasilnya menunjukkan skor tertinggi dari tujuh dimensi OHIP-14 pada dimensi ketidakmampuan fisik. Semakin rendah skor yang didapatkan, semakin baik pula kualitas hidupnya. Didapatkan skor rerata 50,58, sehingga disimpulkan bahwa kualitas hidup manula di Makassar yang menggunakan gigi tiruan lengkap termasuk dalam kategori baik.
\end{abstract}

Kata kunci: gigitiruan lengkap, manula, kualitas hidup

Koresponden: Muzdalifah Solina Berutu.E-mail: muzdalifahsolina@ymail.com

\section{PENDAHULUAN}

Indonesia termasuk negara berstruktur tua. Hal ini terlihat dari persentase manula tahun 2008,2009, dan 2012 telahlebih 7\% dari keseluruhan penduduk; Provinsi Sulawesi Selatan menduduki posisi keenam daerah yang memiliki persentase manula terbanyak. MenurutUUNo.13 tahun 1998, terterabahwa manula adalah seseorang yang telah mencapai usia lebih 60 tahun. Menurut World Health Organization (WHO), manula meliputi usia pertengahan (middle age) atau kelompokusia 45-59 tahun, usia lanjut (elderly) atau kelompokusia 60-74 tahun, usia lanjut tua (old) atau adalah kelompok usia 75-90 tahun, dan usia sangat tua (very old) yang di atas 90 tahun. ${ }^{1-3}$

Proporsi penduduk duniayang berusia lebih dari 60 tahun bertumbuh dengan cepat jika dibandingkan dengan kelompok umur lainnya, dan diperkirakan pada abad ke-21 dari $10 \%$ naik menjadi $25-45 \%$ pada abad ke-22. Di wilayah Asia Tenggara diperkirakan sekitar 142 juta manula atau sekitar $8 \%$ dari populasi, danpada tahun 2025 proporsi populasi lebih dari 60 tahun diprediksi akan dua kali lipat dari tahun 2000 dan pada tahun 2050, akan menjadi tiga kali. ${ }^{4}$

Berdasarkan Riset Kesehatan Dasar (Riskesdas) tahun 2013, persentase penduduk yang mempunyai masalah kesehatan gigi dan mulut dalam 12 bulan terakhir adalah $25,9 \%$; dari jumlah tersebut, yang menerima perawatan atau pengobatan dari tenaga kesehatan gigi sebanyak $31,1 \%$, sementara sisanya tidakmendapat perawatan.Provinsi Sulawesi Selatan termasuk tiga besar provinsi yang memiliki angka prevalensi penduduk yang bermasalah gigi dan mulut yang cukup tinggi, yakni $36,2 \%{ }^{5}$

Gigi memiliki fungsi yang sangat penting bagi kehidupan. Selain untukestetik dan komunikasi, gigigeligi juga berperan besar dalam pemenuhan nutrisi, dengan fungsi mastikasinya. ${ }^{6}$ Kehilangan gigi juga dapat berpengaruh terhadap aktivitas sosial. Hal ini juga selaras dengan pendapat peneliti sebelumnya yang dikutip oleh Emini ${ }^{7}$, yaitu McGrath dan Bedi, bahwa kehilangan gigi dapat mempengaruhi keadaan fisik seperti penampilan estetik, terganggunya sistem 
mastikasi dan mempengaruhi kenyamanan bicara; serta hasil penelitian Wong bahwa kehilangan gigigeligi mempengaruhi keadaan fisik dan psikologis, seperti berkurangnya percaya diri dan keterbatasan aktivitas sosial.

World Health Organization yang dikutip oleh Wangsarahardja, berpendapat bahwa kualitas hidup adalah persepsi seseorang dalam aspek budaya dan norma yang sesuai dengan tempat hidupnya, serta terkait dengan tujuan, harapan, standar dankepedulian selama hidupnya. Kualitas hidup manula dipengaruhi oleh berbagai faktor, antara lain status kesehatan gigidan mulut,jenis kelamin, tingkatpendidikan, dan juga pekerjaan. ${ }^{8}$

Gigitiruanlengkap(GTL) merupakan salah satu perawatan yang sering dipilih pada kasus kehilangan gigi. ${ }^{9-11}$ Pemakaian GTL dapat memperbaiki kualitas hidup manula yang telah mengalami kehilangan gigi. Oleh karenaitu, GTL diharapkan dapat memperbaiki mastikasi yang sudah tidak memadai, memperbaiki estetika, meningkatkan rasa kepercayaan diri dalam bersosialisasi dan meningkatkan kualitas hidupnya.

Oleh karena masalah tersebut, penelitian ini dilakukan untuk mengetahui kualitas hidup manula yang menggunakan GTL di Kota Makassar.

\section{METODE PENELITIAN}

Penelitian observasi analitik dengan desain cross sectional, dilaksanakan pada tiga kecamatan di Kota Makassar dengan menggunakan metode penentuan sampelstratified random sampling, yaitu kecamatan Ujung Tanah, Tamalate dan Ujung Pandang pada bulan Mei-Juni 2014.Kriteria inklusi sampel adalah manula yang berdomisili di Kota Makassar yang berumur lebih atau sama 60 tahun yang kehilangan seluruh giginya dan menggantinya dengan GTL, lama penggunaan GTL minimal dua minggu, mampu berkomunikasi dua arah dengan baik dan bergerak tanpa bantuan orang lain, dan bersedia diwawancarai dan mengikuti seluruh prosedur kegiatan penelitian dengan menyetujui informed consent. Sedangkan manula yang menggunakan GTL namun tidak dapat melihat, mendengar dan berbicara dengan memadai sehingga sulit diwawancarai, penderita penyakit sistemik tidak terkontrol, perokok berat (lebih dari 15 batang sehari) tidak diikutkan dalam penelitian ini. Berdasarkan kriteria tersebut akhirnya diperoleh 162 responden yang diperoleh secara door-to-door.

Pengukuran kualitas hidup dilakukan melalui wawancara dengan menggunakan kuesioner OHIP14,yang terdiri dari tujuh dimensi, yaitu keterbatasn fungsional, rasa sakit fisik, ketidaknyamanan psikis, disabilitas fisik, disabilitas psikis, disabilitas sosial, dan keterhambatanyang dinilai dengan skala Likert; yaitu $0=$ tidak pernah, $1=$ hampir tidak pernah, $2=$ kadang-kadang, 3 = agak sering, $4=$ sangat sering; dengan jumlah skor 0-56. Data lalu dikumpul dan dihitung secara manual; makin tinggi skornya, makin buruk kualitas hidup seseorang. Sebaliknya, makin rendah skornya makin baik pula kualitas hidupnya. Penggolongan kualitas hidup adalah baik, sedang atau cukup, dan buruk. Selain itu, dianalisis dengan chi-square untuk melihat hubungan berbagai faktor terhadap kualitas hidup.

\section{HASIL PENELITIAN}

Tabel 1 Distribusi karakteristik sampel $(\mathrm{N}=162)$

\begin{tabular}{ccc}
\hline Karakteristik sampel penelitian & $\mathrm{n}$ & $(\%)$ \\
\hline Jenis Kelamin & & \\
Perempuan & 127 & 78,4 \\
Laki-laki & 35 & 21,6 \\
Usia & & \\
Elderly (60-74 tahun) & 139 & 85,8 \\
Old (75-90 tahun) & 22 & 13,6 \\
Very old ( $>90$ tahun) & 1 & 0,6 \\
Kecamatan & & \\
Ujung tanah (perifer) & 14 & 8,6 \\
Tamalate (middle) & 125 & 77,2 \\
Ujung pandang (centre) & 23 & 14,2 \\
Pembuat GTL & & \\
Dokter gigi & 72 & 44,4 \\
Perawat gigi & 15 & 9,3 \\
Tukang gigi & 75 & 46,3 \\
Lama penggunaan GTL & & \\
$>5$ tahun & 70 & 43,2 \\
$\leq 5$ tahun & 92 & 56,8 \\
Tidak sekolah & & \\
SD & 33 & 20,4 \\
SMP & 68 & 42,0 \\
SMA & 33 & 20,4 \\
Akademi & 18 & 11,1 \\
S1 / S2 & 3 & 1,9 \\
Latar belakang pendidikan & 7 & 4,3 \\
\hline & &
\end{tabular}

Tabel 1 berisikan karakteristik 162 responden, yang terdiri dari 127 perempuan $(78,4 \%)$ dan 35 lakilaki $(21,6 \%)$ dan usia responden terbanyak pada kisaran 60-74 tahun (elderly) sebanyak 139 responden $(85,8 \%)$. Sedangkan gigi tiruan yang digunakan, lebih banyak dibuat di tukang gigi (46,3\%), dibandingkan doktergigi $(44,4 \%)$. Mengenai kategori pendidikan, responden didominasi manula yang hanya tamat $\mathrm{SD}$ $(42,0 \%)$; berbeda sekali dengan responden dengan tingkat pendidikan S1/S2 (4,3\%).

Kualitas hidup manula yang menggunakan GTL dinilai melalui tujuh dimensi OHIP-14, distribusinya berdasarkanjenis kelamin, baik perempuan maupun laki-laki tergolong baik (tabel2). Penghitungan skor, yaitu dengan mengalikan banyaknya responden yang menjawab sesuai dengan pilihan jawaban alternatif 
Tabel 2 Distribusi kualitas hidup pengguna gigitiruan penuh di Makassar berdasarkan tujuh dimensi OHIP-14 (L = laki-laki, $\mathrm{P}=$ perempuan)

\begin{tabular}{|c|c|c|c|c|c|c|c|c|}
\hline \multirow{3}{*}{ No } & \multirow{3}{*}{ Dimensi OHIP-14 } & \multicolumn{6}{|c|}{ Kualitas Hidup } & \multirow{3}{*}{$\begin{array}{l}\text { Total } \\
\text { (n) }\end{array}$} \\
\hline & & \multicolumn{2}{|c|}{ Baik: n (\%) } & \multicolumn{2}{|c|}{ Sedang: $\mathrm{n}(\%)$} & \multicolumn{2}{|c|}{ Buruk: n (\%) } & \\
\hline & & $\mathrm{L}$ & $\mathrm{P}$ & $\mathrm{L}$ & $\mathrm{P}$ & $\mathrm{L}$ & $\mathrm{P}$ & \\
\hline 1 & Keterbatasan fungsional & $29(82,9)$ & $112(88,2)$ & $4(11,4)$ & $9(7,1)$ & $2(5,7)$ & $6(4,7)$ & 162 \\
\hline 2 & Rasa sakit fisik & $28(80,0)$ & $107(84,3)$ & $7(20,0)$ & $14(11,0)$ & $0(0,0)$ & $6(4,7)$ & 162 \\
\hline 3 & Ketidaknyamanan psikis & $33(94,3)$ & $115(90,6)$ & $1(2,9)$ & $8(6,3)$ & $1(2,9)$ & $4(3,1)$ & 162 \\
\hline 4 & Ketidakmampuan fisik & $28(80,0)$ & $96(75,6)$ & $5(14,3)$ & $23(18,1)$ & $2(5,7)$ & $8(6,3)$ & 162 \\
\hline 5 & Ketidakmampuan psikis & $35(100,0)$ & $123(96,9)$ & $0(0,0)$ & $2(1,6)$ & $0(0,0)$ & $2(1,6)$ & 162 \\
\hline 6 & Keterbatasan sosial & $33(94,3)$ & $123(96,9)$ & $1(2,9)$ & $4(3,1)$ & $1(2,9)$ & $0(0,0)$ & 162 \\
\hline 7 & Keterhambatan & $35(100,0)$ & $122(96,1)$ & $0(0,0)$ & $5(3,9)$ & $0(0,0)$ & $0(0,0)$ & 162 \\
\hline
\end{tabular}

Tabel 3 Kualitas hidup pengguna GTL berdasarkan OHIP-14

\begin{tabular}{|c|c|c|c|c|c|c|}
\hline \multirow{2}{*}{ No } & \multirow{2}{*}{ Dimensi OHIP-14 } & \multirow{2}{*}{ Item OHIP-14 } & \multirow{2}{*}{ Skor } & \multicolumn{3}{|c|}{ Kualitas Hidup } \\
\hline & & & & Baik & Sedang & Buruk \\
\hline \multirow{2}{*}{1} & \multirow{2}{*}{ Keterbatasan Fungsional } & Kesulitan berbicara & 60 & $\sqrt{ }$ & - & - \\
\hline & & Kesulitan mengecap makanan & 74 & $\sqrt{ }$ & - & - \\
\hline \multirow[b]{2}{*}{2} & \multirow[b]{2}{*}{ Rasa Sakit Fisik } & Rasa sakit hebat & 84 & $\sqrt{ }$ & - & - \\
\hline & & Tidak nyaman saat makan & 84 & $\sqrt{ }$ & - & - \\
\hline \multirow{2}{*}{3} & \multirow{2}{*}{ Ketidaknyamanan Psikis } & Merasa cemas & 48 & $\sqrt{ }$ & - & - \\
\hline & & Merasa tegang & 40 & $\sqrt{ }$ & - & - \\
\hline \multirow{2}{*}{4} & \multirow{2}{*}{ Ketidakmampuan Fisik } & Tidak puas makan makanan tertentu & 111 & $\sqrt{ }$ & - & - \\
\hline & & Terganggu saat makan & 95 & $\sqrt{ }$ & - & - \\
\hline \multirow{2}{*}{5} & \multirow{2}{*}{ Ketidakmampuan Psikis } & Kesulitan beristirahat & 15 & $\sqrt{ }$ & - & - \\
\hline & & Merasa malu & 32 & $\sqrt{ }$ & - & - \\
\hline \multirow{2}{*}{6} & \multirow{2}{*}{ Keterbatasan Sosial } & Terganggu oleh orang lain & 26 & $\sqrt{ }$ & - & - \\
\hline & & Kesulitan melakukan pekerjaan & 13 & $\sqrt{ }$ & - & - \\
\hline \multirow{4}{*}{7} & \multirow{2}{*}{ Keterhambatan } & Hidup terasa kurang memuaskan & 18 & $\sqrt{ }$ & - & - \\
\hline & & Ketidakmampuan beraktivitas & 8 & $\sqrt{ }$ & - & - \\
\hline & Total & 708 & & & & \\
\hline & Rerata & 50,58 & & & & \\
\hline
\end{tabular}

Tabel 4 Hubungan jenis kelamin dengan kualitas hidup manula yang menggunakan GTL di Kota Makassar

\begin{tabular}{|c|c|c|c|c|c|c|}
\hline \multirow{2}{*}{ Jenis Kelamin } & \multicolumn{3}{|c|}{ Kualitas Hidup } & \multicolumn{2}{|c|}{ Total } & Nilai $p$ \\
\hline & Baik n (\%) & Sedang n $(\%)$ & Buruk n $(\%)$ & $\mathrm{n}$ & $\%$ & \multirow{4}{*}{0,720} \\
\hline Laki-laki & $34(97,1)$ & $1(2,9)$ & $0(0,0)$ & 35 & 100 & \\
\hline Perempuan & $120(94,5)$ & $5(3,9)$ & $2(1,6)$ & 127 & 100 & \\
\hline Total & $154(95,1)$ & $6(3,7)$ & $2(1,2)$ & 162 & 100 & \\
\hline
\end{tabular}

(A) dengan nilai masing-masing alternatif jawaban (B), yaitu jumlah skor per jawaban pertanyaan $=\mathrm{A} x$ $\mathrm{B}$ (jumlah skor tertinggi $=162 \times 4=648$; jumlah skor terendah $=162 \times 0=0)$.

Data hasil pengukuran secara kontinum untuk Makassar didapatkan kualitas hidup baik dengan skor 0-216, kualitas hidup sedang dengan skor 217-432, dan kualitas hidup buruk dengan skor 433-648.

Pada tabel 3 mengenai kualitas hidup manula pengguna GTLdi Kota Makassar berdasarkan OHIP14 pada 162 sampel, didapatkan skor tertinggi pada dimensi keempat, yaitu pada item tujuh mengenai ketidakpuasan makan makanan tertentu yang dengan jumlah skor 111, sedangkan skor terendah, yaitu pada dimensi ketujuh,item 14 mengenai ketidakmampuan beraktivitas, dengan jumlah skor 8 . Totalnya, secara keseluruhan, mulai dimensi satu hingga dimensi tujuh
OHIP-14, kualitas hidup pengguna GTL di Makassar tergolong baik, karena skornya antara 0-216.

Berdasarkan penghitungan skor OHIP-14 pada 162 responden manula pengguna GTL di Makassar didapatkan jumlah skor 708, yang berarti kualitas hidup manula pengguna GTL di Makassar tergolong baik.

Berdasarkan tabel 4 yakni hubungan antara jenis kelamin dengan kualitas hidup, dapat dilihat rerata kualitas hidupyang baik dari keseluruhan responden, baik laki-laki maupun perempuan, dengan total 154 responden $(95,1 \%)$, kualitas hidup sedang 6 responden $(3,7 \%)$ dan kualitas hidup buruk 2 responden $(1,2 \%)$. Hasiluji statistik dengan chi square didapatkan nilai $p 0,720(>0,05)$ yang artinya tidak ada hubungan antara jenis kelamin dengan kualitas hidup manula yang menggunakan GTL. 
Tabel 5 Hubungan lama penggunaan GTL terhadap kualitas hidup manula di Kota Makassar

\begin{tabular}{ccccccc}
\hline \multirow{2}{*}{ Lama Penggunaan GTL } & \multicolumn{3}{c}{ Total } & \multirow{2}{*}{ Nilai $p$} \\
\cline { 2 - 6 } & Baik n (\%) & Sedang n (\%) & Buruk n (\%) & $\mathrm{n}$ & $\%$ & \\
\hline 5 tahun & $68(97,1)$ & $2(2,9)$ & $0(0,0)$ & 70 & 100 \\
$\leq 5$ tahun & $86(93,5)$ & $4(4,3)$ & $2(2,2)$ & 92 & 100 & \multirow{2}{*}{0,403} \\
\hline Total & $154(95,1)$ & $6(3,7)$ & $2(1,2)$ & 162 & 100 & \\
\hline
\end{tabular}

Tabel 6 Hubungan tempat pembuatan GTL terhadap kualitas hidup manula di Kota Makassar

\begin{tabular}{|c|c|c|c|c|c|c|}
\hline \multirow{2}{*}{ Tempat Pembuatan GTL } & \multicolumn{3}{|c|}{ OHIP-14 } & \multicolumn{2}{|c|}{ Total } & \multirow{2}{*}{ Nilai $p$} \\
\hline & Baik n $(\%)$ & Sedang n (\%) & Buruk n (\%) & $\mathrm{n}$ & $\%$ & \\
\hline Dokter gigi & $70(97,2)$ & $2(2,8)$ & $0(0,0)$ & 72 & 100 & \multirow{4}{*}{0,214} \\
\hline Perawat gigi & $14(93,3)$ & $0(0,0)$ & $1(6,7)$ & 15 & 100 & \\
\hline Tukang gigi & $70(93,3)$ & $4(5,3)$ & $1(1,3)$ & 75 & 100 & \\
\hline Total & $154(95,1)$ & $6(3,7)$ & $2(1,2)$ & 162 & 100 & \\
\hline
\end{tabular}

Tabel 7 Hubungan tingkat pendidikan terhadap kualitas hidup manula pengguna GTL di Kota Makassar

\begin{tabular}{|c|c|c|c|c|c|c|}
\hline \multirow{2}{*}{ Tingkat Pendidikan } & \multicolumn{3}{|c|}{ OHIP-14 } & \multicolumn{2}{|c|}{ Total } & \multirow{2}{*}{ Nilai $p$} \\
\hline & Baik n (\%) & Sedang n (\%) & Buruk n (\%) & $\mathrm{n}$ & $\%$ & \\
\hline Tidak sekolah & $31(93,9)$ & $1(3,0)$ & $1(3,0)$ & 33 & 100 & \\
\hline $\mathrm{SD}$ & $65(95,6)$ & $3(4,4)$ & $0(0,0)$ & 68 & 100 & \\
\hline SMP & $31(93,9)$ & $1(3,0)$ & $1(3,0)$ & 33 & 100 & \\
\hline SMA & $17(94,4)$ & $1(5,6)$ & $0(0,0)$ & 18 & 100 & 0,952 \\
\hline Akademi & $3(100,0)$ & $0(0,0)$ & $0(0,0)$ & 3 & 100 & \\
\hline $\mathrm{S} 1 / \mathrm{S} 2$ & $7(100,0)$ & $0(0,0)$ & $0(0,0)$ & 7 & 100 & \\
\hline Total & $154(95,1)$ & $6(3,7)$ & $2(1,2)$ & 162 & 100 & \\
\hline
\end{tabular}

Berdasarkan tabel 5, diketahui bahwa dari 162 responden, yang memiliki kualitas hidup baik dengan penggunaan GTL $>5$ tahun sebanyak 62 responden $(97,1 \%)$, kualitas hidup sedang 2 responden $(2,9 \%)$, penggunaan GTL $\leq 5$ tahun kualitas hidup baik 86 responden(93,5\%).Dengan uji chi square didapatkan nilai $p=0,403(>0,05)$, tidak ada hubungan antara lama penggunaan GTL terhadap kualitas hidup.

Pada tabel 6 dapat dilihat dari 162 responden, yang membuat GTL di dokter gigi, 72 responden $(100 \%)$ dengan kualitas hidup yang baik sebanyak 70 responden $(97,2 \%)$. Pada perawat gigi, responden dengan kualitas hidup baik sebanyak $14(93,3 \%)$ dan kualitas hidup buruk 1 responden (6,7\%) sedangkan yang membuat gigitiruan pada tukang gigi sebanyak 70 responden $(93,3 \%)$ dengan kualitas hidup baik dan satu responden $(1,3 \%)$ memiliki kualitas hidup yang buruk. Pada hasil uji chi square antara tempat pembuatan GTL kaitannya dengan kualitas hidup, didapatkan nilai $p$ yaitu $0,214(>0,05)$ yang berarti tidak ada hubungan antara tempat pembuatan GTL terhadap kualitas hidup manula.

Pada tabel 7 hasil uji chi square untuk hubungan tingkat pendidikan terhadap kualitas hidup diperoleh nilai $p 0,952(\mathrm{p}>0,05)$, berarti tidak ada hubungan tingkat pendidikan dengan kualitas hidup manula yang menggunakan GTL di Makassar.

\section{PEMBAHASAN}

Penelitian ini menggunakan kuesioner OHIP14 dengan tujuh dimensi, kemudian dilakukan uji chi- square dengan menggunakan SPSS untuk melihat hubungan antara faktor-faktor yang mempengaruhi kualitas hidup manula yang memakai GTL. Dimensi ketidakmampuan fisik dan rasa sakit fisik merupakan dua dimensi dengan keluhan tertinggi; ketidakpuasan dan rasa tidak nyaman dalam hal mastikasi. Pada hal ini, ada beberapa responden yang mengeluhkan gigitiruan rahang bawahnya longgar, sehingga sering sulit mengunyah makanan, dan potensi mastikasi yang berbeda saat masih menggunakan gigi alami sehingga kadang tidak puas makan makanan tertentu.

Hal tersebut mirip dengan penelitian terdahulu yang dilakukan oleh Carmen $\mathrm{dkk}^{9}$ bahwa pemakaian GTL berdampak negatif terhadap OHRQoL pada pasien manula, terutama pada dimensi keterbatasan fungsional dan rasa sakit fisik. Hal ini disebabkan GTL pada rahang atas lebih nyaman daripada GTL pada rahang bawah. Pasien seringkali mengeluhkan ketidakpuasannya pada stabilitas retensi dan sulit untuk mengunyah dan berbicara.

Pada tabel 4 mengenai hubungan jenis kelamin terhadap kualitas hidup pengguna GTL didapatkan $p>0,05$ yang artinya tidak ada hubungan antara jenis kelamin dengan kualitas hidup. Meskipun jumlah sampel laki-laki dan perempuan jauh berbeda, yakni 35 dan 127, tetapi keduanya menunjukkan kualitas hidup yang baik.

Begitupun pada tabel 5 mengenai hubungan lama penggunaan GTL terhadapkualitas hidup didapatkan nilai $p>0,05$, yang berarti tidak ada hubungan lama penggunaan. Hal ini selaras dengan hasil penelitian 
Nazdrajic ${ }^{10}$ mengenai lama penggunaan gigitiruan tidak mempunyai dampak besar terhadap kualitas hidup, yakni pasien yang menggunakan GTL lebih dari lima tahun memiliki kualitas hidup yang lebih baik, akan tetapi perbedaan tersebut tidak terlalu berarti. Hasil yang didapatkan penulis di lapangan, ada responden yang telah menggunakan gigitiruan selama puluhan tahun tetapi gigitiruannya tetap dapat berfungsi dengan baik. Hal tersebut karenaresponden tersebut rajin membersihkan gigi tiruannya secara rutin danmerawat gigi tiruannya dengan baik. Semua tergantung dari individu masing-masing,karenayang akan menggunakan dan merawat gigitiruan adalah individu tersebut sendiri.

Pada tabel 6 mengenai hubungan tempat pembuat gigitiruan dengan kualitas hidupnya tidak terdapat hubungan bermakna, yaitu nilai $p 0,214(\mathrm{p}>0,05)$. Kecendrungan manula pada penelitian ini memilih tukang gigi untuk membuat gigi tiruannya. Meskipun dalam hal ini, perbedaan jumlah yang sedikit antara responden yang membuat gigi tiruan di tukang gigi dan pada dokter gigi. Hal ini mengejutkan penulis, sekaligus sedih mengetahui masyarakat sekarang ini masih lebih mempercayakan urusan gigi tiruannya kepada tukang gigi, karena masalah biaya yang lebih murah dan mudah dijangkau. Bahkan terkadang ada anggota masyarakat yang masih sulit membedakan antara dokter gigi dan tukang gigi.

Akan tetapi, tidak ada yang dapat menjamin, bahwa buatan dokter gigi lebih memuaskan pasien daripada buatan tukang gigi ataupun perawat gigi, begitupun sebaliknya. Hal itu cukup mengejutkan penulis karena berdasarkan data yang didapatkan, manula yang menggunakan GTL yang dibuat oleh tukang gigi terkadang juga tidak terdapat keluhankeluhan tentang gigi tiruannya. Hasil yang diperoleh yaitu kualitas hidupmanulayang membuat gigi tiruan pada dokter gigi maupun pada tukang gigi memiliki kualitas hidup baik.

Penelitian Kaunang $\mathrm{dkk}^{11}$ mendapatkan bahwa alasan responden lebih memilih tukang gigi sebagai tempat pembuatan gigitiruannya karena biaya yang relatif murah, lebih cepat dari segi waktu, dan akses tempat tukang gigi; tukang gigi bekerja lebih cepat bahkan tukang gigi dapat dipanggil ke rumah warga untuk dibuatkan gigi tiruan tanpa perlu menunggu lama. Hal ini sama dengan yang penulis dapatkan dilapangan, bahkan ketika gigi tiruannya mengalami masalah, responden hanya menghubungi tukang gigi dan kemudian tukang gigi yang akan datangke rumah tanpa harus antri ataupun menunggu lama; berbeda ketika hal tersebut dilakukan di dokter gigi.

Sebanyak 68 responden $(42 \%)$ memiliki tingkat pendidikan SD; kemungkinan tingkat pengetahuan mengenai kesehatan gigi dan mulut minim, sehingga perlu diberi penyuluhan tentang pentingnya menjaga kesehatan gigi dan mulut, khususnya pada manula yangmenggunakan GTL.Masih banyakmanula yang tidakmengetahui risiko yang dapat ditimbulkan dari penggunaan GTL yang dibuat tukang gigi. Kaunang $\mathrm{dkk}^{11}$ pada penelitiannya diDesa Treman pada tahun 2013 menyatakan bahwa masih ada responden yang belum paham perbedaan kompetensi tukang gigi dan dokter gigi. Mereka beranggapan bahwa pembuatan gigitiruan oleh tukang gigi sama dengan pembuatan gigitiruan yang dibuat oleh dokter gigi. Oleh karena itu diperlukan edukasi mengenai kesehatan gigi dan mulut oleh para tenaga kesehatan, khususnya dokter gigi kepada masyarakat.

Pada penelitian ini didapatkan skor 50,58, yaitu kualitas hidup manula yang menggunakan GTL di Makassar tergolong baik. Penelitian yang dilakukan Davis dkk di London, yang dikutip oleh Kaunang, ${ }^{11}$ menunjukkan bahwa $45 \%$ orang yang kehilangan gigi sulit menerima keadaannya dan merasa kurang percaya diri sehingga tidak ingin dilihat orang lain saat tidak memakai gigi tiruan. Dengan adanya gigi tiruan untuk menggantikan gigi yang hilang dapat mengembalikan rasa percaya diri sehingga gangguan akan kehilangan gigi dapat diatasi.

Hasil penelitian, Hussain $\mathrm{dkk}^{12}$ menyimpulkan bahwa pemakaian GTL penting untuk mendapatkan kualitas hidupyang memadai pada manula yang telah kehilangan gigi, karena secara langsung memiliki dampak positif terhadap aktivitas sosial, mental dan psikologisnya. Begitu juga hasil penelitian Adam ${ }^{13}$ bahwa penggunaan GTL pada manula menyebabkan mereka tidak pernah merasakan tidak nyaman karena makanan yang tersisa, tidak pernah merasa malu, tidak pernah menghindari makanan dan tidak pernah malu untuk tersenyum. Oleh karenanya, penggunaan GTL dapat meningkatkan kualitas hidup manula yang telah mengalami kehilangan gigi.

Berdasarkan hasil penelitian ini, disimpulkan bahwa kualitas hidup manula yang memakai GTL di Makassar tergolong baik. Adapun dimensi yang paling sering dikeluhkan adalah ketidakmampuan fisik, dalam hal ini manula merasa tidak puas saat mengkonsumsi makanan tertentu dan sering merasa terganggu saat sedang makan ketika menggunakan gigi tiruan.

Untuk itu disarankan perlu diadakan penyuluhan mengenai kesehatan gigi dan mulut kepada manula khususnya manula yangmenggunakan GTL, tentang cara merawat gigi tiruan, waktu yang tepat untuk mengganti gigi tiruannya, serta risiko penggunaan gigi tiruan yang dibuat oleh tenaga non-profesional, dalam hal ini tukang gigi. 


\section{DAFTAR PUSTAKA}

1. Pusat data dan Informasi Kemenkes RI. Gambaran kesehatan lanjut usia di Indonesia [internet] Juli 2013. Available from: URL: http://www.depkes.go.id/downloads/Buletin\%20Lansia.pdf. Accessed December 12 $2^{\text {th }}, 2013$

2. Undang-Undang RI nomor 13 tahun 1998 tentang kesejahteraan lanjut usia [internet]. Available from: URL: http:// www.bpkp.go.id/uu/filedownload/2/45/438.bpkp. Accessed December $12^{\text {th }}, 2013$

3. Anonim. Gerontologi [internet]. Available from: URL: http://healthyenthusiast.com/gerontologi.html. Accessed December $14^{\text {th }}, 2013$.

4. Irwan, Retty. Long term care [internet]. Available from: URL: http://www.komnaslansia.go.id. Accessed December $11^{\text {th }}, 2013$

5. Badan Penelitian dan Pengembangan Kesehatan Kementerian Kesehatan RI. Riset kesehatan dasar 2013. Available from: URL: depkes.go.id/downloads/riskesdas2013/Hasil\%20Riskesdas\%202013.pdf. Accessed April 10 ${ }^{\text {th }}, 2014$

6. Alimin NH, Daharudin H, Harlina. Nutrisi pada pengguna gigitiruan penuh. J Dentofasial 2013; 12(1): 64

7. Emini. Gigitiruan dan perilaku ibadah. J Health Quality 2013; 4(1): 28,30-1

8. Wangsarahardja K, Dharmawan OV, Kasim E. Hubungan antara status kesehatan mulut dan kualitas hidup pada lanjut usia. Universa Medicina 2007; 26(4): 188,190

9. Carmen P, Maria JSG, Jaime DR, Daniel TL, Javier M, Raquel CO. Oral health-related quality of life in complete denture wearers depending on their socio-demographic background, prosthetic-related factors and clinical condition. Med Oral Patol Oral Cir Bucal 2013; 18(3): e379

10. Nazdrajic AH. Quality of life with removable dentures. MSM 2011; 23(4): 218

11. Kaunang WPJ, Aurella S, Ayu A. Persepsi masyarakat terhadap pembuatan gigitiruan oleh tukang gigi di Desa Treman Kecamatan Kauditan. Available from: URL: http://ejournal.unsrat.ac.id. Accessed $22^{\text {nd }}$ August, 2014

12. Hussain SZ, Shujaat NG, Idris SH, Chatha MR. Oral health related quality of life (OHRQoL) in 40 to 70 years. Pak Oral Dent J 2010; 30(2): 530

13. Adam RZ. Do complete dentures improve the quality of life of patients? [dissertation]. Faculty of Dentistry and World Health Organisation (WHO) Oral Health Collaborating Centre: University of the Western Cape; 2006 